\title{
We Can Do Better: Why Pastoral Care Visitation to Hospitals is Essential, Especially in Times of Crisis
}

\author{
Daniel E. Hall ${ }^{1,2,3}$ (D \\ Published online: 30 July 2020 \\ (c) Springer Science+Business Media, LLC, part of Springer Nature 2020
}

\begin{abstract}
From his perspective as a general surgeon, Episcopal priest and Medical Director for High Risk Populations and Outcomes at a large health-care system, the author identifies an unrecognized problem that clergy were banned from visiting parishioners in most hospitals across the country during the height of the Covid-19 pandemic - a situation that persists in many contexts. The author explains why pastoral visitation should be considered essential care-especially at a time of crisis-and encourages hospital administrators across the country to clarify policies to welcome community clergy as essential personnel, but to do so with prudent procedures that mitigate risk to the community and to the visiting clergy. Given the fact that most hospitals in this country were founded by religious organizations and still carry the imprint of that founding in their names, it would be tragic for these very same hospitals to cut patients off from their religious communities precisely at the time they need them most.
\end{abstract}

Keywords Covid-19 · Pastoral care · Pastoral visitation · Quality improvement · Hospital administration

Electronic supplementary material The online version of this article (https://doi.org/10.1007/s1094 3-020-01072-x) contains supplementary material, which is available to authorized users.

Daniel E. Hall

hallde@upmc.edu

1 Center for Health Equity Research and Promotion, VA Pittsburgh Healthcare System, Pittsburgh, PA, USA

2 Department of Surgery, University of Pittsburgh, Pittsburgh, PA, USA

3 Wolff Center, University of Pittsburgh Medical Center, UPMC Presbyterian, Suite 1264, 200 Lothrop St, Pittsburgh, PA 15213, USA 


\section{Introduction}

As a practicing general surgeon, Episcopal priest and Medical Director for High Risk Populations and Outcomes across the UPMC health system in Pittsburgh, my life's work has been dedicated to helping physicians reimagine surgical success such that patients are cared for even when our efforts to cure disease are unsuccessful (Hall 2020).

So I was particularly alarmed to learn from colleagues across the country that clergy were blocked from visiting hospitalized members of their religious communities during the Covid-19 pandemic (Lehigh Valley Health Network, March 29, 2020; University of Maryland Medical System, March 20, 2020; WellSpan Health, March 21, 2020). Whether intentionally or inadvertently, hospital policies restricting visitors to "essential" staff were interpreted by many-including clergy themselves - to apply to community-based clergy. In more than one case, I know that a dying patient was denied access to their priest of long standing, with even attempts to pass a telephone to the patient's ear for words of comfort and prayer being rebuffed by hospital staff. We can do better.

Most hospitals across the USA were founded by religious communities. In Pittsburgh alone, the hospitals are named Presbyterian, Mercy (Roman Catholic), St. Margaret (Episcopalian), Passavant (Lutheran, after pastor William Passavant), and Montefiore (Jewish), to name a few. There were no charity hospitals in antiquity (Ferngren 2009); caring for the sick simply because they needed care was introduced later by monastic communities to embody the specific virtue of hospitality (Crislip 2005). Caring even when cure is not possible is baked into the foundation of our hospitals. Cutting patients off from their communities of religious support is short sighted, especially in a time when medical technology is often powerless to protect from this virus. We need the support and assistance of our clergy colleagues.

\section{Pastoral Care is Essential-Especially in Times of Crisis}

Pastoral care is essential for those who seek it because personal and public health are not the only human values worth pursuing-even in a pandemic. Don't get me wrong, health is very, very important, but as Shakespeare observed through Hamlet: "There are more things in heaven and earth, Horatio, than are dreamt of in your philosophy" (Act 1, Sc 5). Illness of all kinds isolates the sick and divides them from the relationships that make life worth living and on which our shared lives depend. Such isolation and dis-membering are a source of great suffering for those with disease. Pastoral visitation targets this suffering-not as an "effective" cure, but as a witness to the enduring interdependence of the human condition, restoring the sick person to relationship through the pastoral visitor. Such witness preserves our humanity - the humanity of the patient, the pastoral visitor and all those who surround them. 
As we have done at UPMC, I encourage hospitals to clarify policies regarding the ongoing pastoral and spiritual needs of patients. In many cases, the restrictive interpretation of the policy may be an oversight or unintended consequence of policies created in appropriate haste. I raised my concerns on March 26, 2020, and by April 1st the policy had been clarified to recognize community clergy as essential personnel who should be welcomed to render pastoral visitation pursuant to standard screening precautions (UPMC 2020). It took additional time to secure routine access to patients in isolation precautions, but by May 18th clergy were allowed routine access to all patients, including those known to have Covid19 and those under investigation (UPMC 2020). Indeed, the questions raised about clergy visitation catalyzed further discussion culminating in a broader policy, also implemented May 18th, permitting each inpatient to identify one support person who could attend their bedside in person, regardless of Covid-19 status. Although clearly articulated on the public-facing Web site, these policies are still not widely appreciated by local clergy, but the word is getting out thanks to coverage in the local press (Smith 2020).

Hospital-employed chaplains should continue to provide care on-site as usual, but they cannot be all things to all people. Pastoral care is best when rendered by and within a particular religious tradition, and thus, local clergy should be permitted to visit individuals from their religious communities. These local clergy should be encouraged to exercise discretion and creativity to minimize physical contact as much as would be consistent with good pastoral care, but they should be welcomed as essential partners in providing excellent health care in all its dimensions during these extraordinary times. Model procedures for safely rendering pastoral care in the time of a pandemic are included in appendix (online supplement). It is not too late to put these policies in place, even as the worst of the crisis seems to have passed. There may be regional outbreaks where such policy clarification may be needed. And establishing the policy now may prevent similar misunderstanding if and as future pandemics or similar crises emerge.

\section{Pastoral Visitors Should Follow Standard Precautions to Minimize Risks of Transmission}

Let me be clear: I do not condone the shameful and outrageous behavior of some clergy and religious organizations that deliberately sabotage prudent attempts to mitigate viral spread (Mazzei 2020). Clergy must be held accountable for safe practices, and most will do so responsibly. Many will also work to leverage telehealth solutions for remote pastoral care. But ignoring the pastoral needs of patients is not an option. Two-thirds of surveyed patients consider spiritual support essential care, even more so at the end of life (Balboni et al. 2013; Koenig 1998; MacLean et al. 2003; Steinhauser et al. 2000).

Pastoral care should be available for both those with and without active infection. Many people remain in hospital for reasons other than COVID-19, and there is little risk in visiting these. More caution will be needed to visit the infected, but like all essential personnel admitted to health care facilities, local clergy should be screened 
for infection and trained in the proper use of personal protective equipment, or PPE. And hospital administrators should work with local religious leaders to develop safe techniques for prayer, laying on of hands, anointing with oil and last rites.

Some may worry that such policies could lead to unnecessary waste of PPE. This is a valid concern, but by what criteria do we define what is "necessary"? Not everything that matters can be measured, and not everything measured matters. It may be worthwhile for the patient (and for those who surround them) to expend a limited resource to honor and maintain the human dignity of a dying person through pastoral visitation. I'm not suggesting that clergy consume PPE carelessly. Like other essential workers, they may be issued a single mask and be asked to preserve it for use on multiple occasions. Not all will have courage and grace sufficient to minister in this context, but history teaches that clergy will likely be willing to risk their own lives to render needed care.

\section{Conclusion}

Not all will agree with me, and at some point, my argument must abandon the secular idiom to speak in distinctly theological terms: In his letter to faithful Christians in Rome, St. Paul reassures them that neither death, nor life, nor powers, nor principalities, nor things present nor things to come, nor height, nor depth-nothing, not even Covid-19- can separate us from the love of God in Christ Jesus, whose hands and feet are made up by his people on earth called the Church. To deny Christians the chance to embody this truth that endures even as the technical powers of medicine fail would be a tragedy worthy of Shakespeare. And to deny this kind of witness to people of any faith in institutions founded by religious communities would be the epitome of irony.

Funding There was no funding source associated with this manuscript.

\section{Compliance with Ethical Standards}

Conflict of interest The author has no conflicts of interest to disclose.

Ethical Standards This manuscript complies with all applicable ethical standards.

Informed Consent Human subjects were not involved, and thus, neither IRB review nor informed consent applies to this opinion essay.

\section{References}

Balboni, T. A., Balboni, M., Enzinger, A. C., Gallivan, K., Paulk, M. E., Wright, A., et al. (2013). Provision of spiritual support to patients with advanced cancer by religious communities and associations with medical care at the end of life. JAMA Internal Medicine, 173(12), 1109-1117. https://doi. org/10.1001/jamainternmed.2013.903. 
Crislip, A. T. (2005). From monastery to hospital: Christian monasticism and the transformation of health care in late antiquity. Ann Arbor, MI: University of Michigan Press.

Ferngren, G. B. (2009). Medicine and health care in early Christianity. Baltimore, MD: The Johns Hopkins University Press.

Hall, D. E. (2020). Reimagining surgical success-caring for those who die despite our best efforts. JAMA Surgery. https://doi.org/10.1001/jamasurg.2019.5084.

Koenig, H. G. (1998). Religious attitudes and practices of hospitalized medically ill older adults. International Journal of Geriatric Psychiatry, 13(4), 213-224. Retrieved from http://onlinelibrary.wiley .com/doi/10.1002/(SICI)1099-1166(199804)13:4<213::AID-GPS755>3.0.CO;2-5/abstract.

Lehigh Valley Health Network. (March 29, 2020). What is LVHN's hospital and outpatient visitation policy during COVID-19 outbreak? Retrieved from https://www.lvhn.org/patient_visitor_information.

MacLean, C. D., Susi, B., Phifer, N., Schultz, L., Bynum, D., Franco, M., et al. (2003). Patient preference for physician discussion and practice of spirituality. Journal of General Internal Medicine, 18(1), 38-43. Retrieved from http://pubmedcentralcanada.ca/picrender.cgi?accid=PMC1494799\&blobt ype $=$ pdf.

Mazzei, P. (2020, March 31). Pastor arrested after holding packed Sunday services. The New York Times, p. 10.

Smith, P. (2020, June 7). UPMC Clarifies clergy visitation policy. Pittsburgh Post-Gazette. Retrieved from https://pg-share.newsslide.com/4ad5ae97-954a-494d-822f-dc45396843c0/0c50144e-c6b94f3f-a8da-3cdd86daf56a/.

Steinhauser, K. E., Christakis, N. A., Clipp, E. C., McNeilly, M., McIntyre, L., \& Tulsky, J. A. (2000). Factors considered important at the end of life by patients, family, physicians, and other care providers. JAMA, 284(19), 2476-2482. Retrieved from http://jama.ama-assn.org/content/284/19/2476. long, http://jama.ama-assn.org/content/284/19/2476.full.pdf.

University of Maryland Medical System. (March 20, 2020). Temporary visitor restrictions. Retrieved from https://www.umms.org/coronavirus/temporary-visitor-restrictions.

UPMC. (2020). COVID-19 clergy visitation policy (See under Essential Health Providers and Vendors). April 2, 2020. Retrieved from https://www.upmc.com/coronavirus/visitor-restrictions.

WellSpan Health. (March 21, 2020). WellSpan visitor restrictions. Retrieved from https://www.wellspan. org/coronavirus/wellspan-visitor-restrictions/.

Publisher's Note Springer Nature remains neutral with regard to jurisdictional claims in published maps and institutional affiliations. 